\title{
9. The 2010 Federal Election: The Liberal Party
}

\author{
Brian Loughnane
}

The 2010 federal election campaign was one of the most remarkable in Australian history. Key elements of the election result include

- a net gain of 14 seats by the Coalition (including seats that became notionally Labor following redistributions)

- a net loss of 16 seats by Labor

- the first time a first-term government had lost its majority since 1931

- the largest loss of seats by a first-term government since 1931

- the fourth-highest number of seats lost by Labor in its history-only losing more seats in 1931, 1975 and 1996

- the Coalition received almost 700000 more primary votes than Labor; on a two-party preferred basis, the ALP achieved 30527 more votes than the Coalition

- Labor's primary vote (37.99 per cent) was the third-lowest recorded by Labor since 1949

- on a two-party preferred basis, the election result (50.12:49.88 per cent) was the second-closest since 1949, and represented a 2.6 per cent swing to the Coalition

- Labor won nine seats on preferences after trailing on primary vote.

Post-election analysis of the vote reveals interesting trends

- a primary-vote swing against Labor in every State except Tasmania

- two-party preferred swings varied across the country: the Coalition recorded positive two-party preferred swings in Queensland (+5.6 per cent), New South Wales $(+4.8$ per cent), the Northern Territory ( +4.6 per cent), Western Australia (+3.2 per cent) and the Australian Capital Territory (+1.7 per cent), but recorded negative swings in Tasmania $(-4.4$ per cent), Victoria $(-1$ per cent) and South Australia ( -0.8 per cent)

- at this election, the Greens' primary vote reached double digits in all States for the first time; NSW voters are the least supportive of the Greens while those in Tasmania and Western Australia are the most supportive; overall, 60 per cent of seats recorded a Greens primary vote of more than 10 per cent 
- the Coalition won three more Senate seats than the ALP - the ALP's secondworst Senate result since 1984

- the Greens won a Senate seat in each State for the first time at a single election, with the ALP reduced to winning only two Senate positions in each State, except Tasmania

- of concern, the number of informal votes increased by 1.6 per cent nationally; 26 of the 30 highest informal votes were recorded in New South Wales and Queensland - the States with optional preferential voting for State elections

- the number of enrolled people turning out to vote is falling (from 95.8 per cent in 1996 to 93.2 per cent in 2010); in 1996, 92.7 per cent of all enrolled voters lodged a formal vote; in 2010, that number had fallen to 88 per cent

- some commentators have argued that the result was a protest against both major parties. In fact, while the major-party combined vote was marginally down on the previous two elections, it was above the 2001 and 1998 results. In the past six elections, the combined major-party vote peaked when there was a change of government in 1996 and 2007.

The reasons for the results recorded at this election are complex. Aided by Liberal Party research conducted following the election, I will set out below in some detail the factors we believe influenced the result. And though the campaign was an important influence on the result, it was far from the only influence. To properly understand what happened on 21 August, we must begin with the community expectations that Labor itself created in the lead-up to the 2007 election.

Despite significant hesitation, the community gave Labor a mandate in 2007 to implement what Australians considered significant promises to help make their lives better. Doubts about Labor's commitment to deliver on their promises, however, quickly began to appear.

We first saw those hesitations emerge in our research prior to Labor's first budget in 2008. Understandably, however, people found reasons to put off making a judgment, believing the budget would be the moment Labor would start to deliver on its promises. The Prime Minister and Treasurer at the time raised expectations with their talk of tough decisions.

The 2008 budget was a failure for Labor and marked the beginning of its electoral decline. Australians were underwhelmed by the budget and by the lack of any significant action on the issues for which Labor had sought and been given a mandate. The failure of the budget was quickly compounded by Labor's ambivalence towards rising petrol and grocery prices, and manifested itself in the swing against Labor at the Gippsland by-election. 
Brendan Nelson's reply to the budget in May 2008 captured the mood of ordinary Australians and was the beginning of the Coalition's re-emergence as a viable alternative after the 2007 election. Brendan Nelson deserves great credit for instinctively understanding and clearly articulating both the expectations of Labor and the disappointment widely felt with the government across the community.

By mid-2008, our research was showing that while support for Rudd was apparently high, behind these top-line numbers were very deep frustrations. Labor appeared to ordinary Australians to be ignoring their legitimate concerns and obsessed with its own priorities and interests. This was particularly true of Kevin Rudd. Just seven months into office, Labor had begun to lose its way.

The government did receive some initial credit for its approach at the beginning of the global financial crisis. As the stimulus roll-out occurred throughout 2009, however, concern within the community quickly developed. Australians believed schools could use additional funding but were frustrated at the bureaucratic and poorly considered edict that the money had to be spent on school halls when, in many cases, there were obviously other clear priorities for their school.

The concern in the community at Labor's level of waste was deep. The schoolhalls and insulation fiascos cut through as practically every community in Australia had examples of mismanagement and waste and this was made worse by the government's exaggerated rhetoric and refusal to admit any level of problem.

The community reaction to the 2009 budget was that the government lacked a clear strategy to manage the economy and, in particular, to begin to repay debt. A sense began to grow that the government was losing control of the nation's finances with little to show in return. The time had come to begin delivering practical results on the ground, but instead the rhetoric continued, the debt grew and interest rates began increasing.

As he moved around the community, Malcolm Turnbull heard these concerns and articulated them. In contrast, Kevin Rudd and Labor continued to dismiss them, further fuelling community concern. Our feedback on Kevin Rudd in this period included representative comments such as: 'marvellous vision but can't put it into action', 'struggles to know how to implement things', 'badly targeted spending', 'always overseas' and 'just waiting for an opinion poll'.

It was clear to us the community had deep reservations about Labor and Kevin Rudd, after only two years in government, even if those reservations were not yet fully reflected in published opinion polls. The community was looking for a 
strong alternative and an opportunity was emerging for the Coalition. The latter part of 2009, however, was one of the most difficult periods in the history of the Liberal Party.

Labor was attempting to use its proposed emissions trading scheme (ETS) as an issue as much to divide the Coalition as to legislate what it considered to be important policy. As a consequence of the public spotlight being on us, growing community concerns with the Rudd Government were ignored. But they were there, they were real and they were growing. The community was actually more worried in this period about the inaction of the government than it was about the Opposition.

This is why Tony Abbott was able to so quickly and effectively unite the Coalition and take the fight to Labor. People wanted Labor held to account and wanted a strong alternative, and Tony Abbott provided that from the moment he became leader.

It also helps to explain the apparently sudden and dramatic collapse in support for Kevin Rudd. From our perspective, the collapse was neither sudden nor dramatic. As mentioned earlier, the signs of trouble for Rudd were there as early as six months into his term as Prime Minister. Rudd was cut an enormous amount of slack by the electorate. They wished him well. They wanted him to succeed. But Labor's performance never matches its rhetoric. Australians were waiting for something to change but after two years the government's priorities seemed to be overseas travel, photo opportunities and process rather than outcomes to improve people's lives.

In a professional political sense, Rudd was one of the most effective framers of a message we have ever seen in this country. But this was both his strength and the basis of his failure. He effectively positioned climate change as 'the great moral challenge of our time'. People believed he was serious and that he would do something about it. The failure of the Copenhagen climate change conference came as the wider frustrations of the community with Labor were coming to the surface. Why take 114 people to a conference unless you were certain it was going to achieve something? And what did the much-anticipated failure of the conference say about a leader's judgment?

After Copenhagen, people expected Rudd to find other ways to take action. Instead, he abandoned the ETS and moved to introduce a new tax on the mining sector - considered by most Australians a critical driver of our prosperity. This was the moment of no return for Rudd and the final straw that broke the very strained bond of trust he had with the Australian community. 
Even a few months earlier, the Liberal Party would not have been able to use humour and ridicule against Kevin Rudd. But community sentiment had moved so quickly that our 'Kevin O'Lemon' advertisement accurately captured the mood.

We had obviously considered the possibility of Labor changing leaders before the election - indeed, we had prepared for it - so our campaign was able to quickly adapt to Julia Gillard. What was surprising, however, was the speed with which the Gillard skyrocket returned to earth.

As Deputy Prime Minister, Julia Gillard was directly linked to every major decision of the Rudd Government and as a minister was personally responsible for a significant number of the major failures. So while we thought the change would not fundamentally alter the community's problems with Labor, we did think she would have a longer honeymoon.

But after only three weeks it was clear the community's concern and frustration remained and that the way Kevin Rudd was removed by the faceless operatives of the Labor machine had, in fact, created a new and very deep hesitation about Labor.

Labor itself was obviously finding that Gillard's replacement of Rudd had not reversed its decline. The decision of the Labor machine to call the election early seemed to us not to have been a considered strategic decision, but rather an attempt to move the focus away from the day-to-day bungles that threatened to overwhelm the new Prime Minister.

Nonetheless, the task for the Coalition in the campaign was formidable. No first-term government had lost its majority since 1931. After the series of redistributions in New South Wales, Queensland, Western Australia, Tasmania and the Northern Territory, we needed to win 17 seats to obtain a majority. And Labor, of course, had the full advantage of incumbency to support it, together with the additional resources of the industrial arm of the labour movement and various complicit so-called third-party groups such as GetUp!.

Despite this, and given the challenges we faced throughout the term of parliament, our position at the start of the campaign was stronger than we would have expected even a few short months before. Tony Abbott's principled and decisive leadership had put us in a competitive position and had staked out clear policy positions. He had united the parliamentary team, seen off a firstterm prime minister, restored the party's morale and established the Coalition as a credible alternative government. We were therefore able to begin campaigning strongly from the moment the election was called. 
Our success in setting the strategic direction of the contest in the first week of the campaign was very important. Had we not laid the basis then, Labor's internal difficulties in the second and third weeks, while certainly not unhelpful, would have smothered any attempt by us to establish the terms of the contest.

Contrary to Labor's attempts to write their own history, the leaks from within Labor were not per se what had such a catastrophic impact on their campaign. Rather, it was the subject matter of the leaks and the fact that Julia Gillard failed to deny that she had opposed the introduction of paid parental leave; that she had opposed pension increases on the grounds that older Australians did not vote for Labor anyway; that she had sent a relatively junior staff member in her place to meetings of the National Security Committee of Cabinet; and that she failed to consult Cabinet about her citizens' assembly policy.

This focused voters' attention on the fact that Julia Gillard was not the politician Labor spin doctors wanted Australians to think she was. Those responsible for these internal Labor leaks in fact exposed the real Julia. In contrast, Tony Abbott was seen as a person with strong principles, highly disciplined, intelligent, energetic and with an easy rapport with people on the campaign trail.

In this campaign, every day mattered. In 2007, 68 per cent of voters told us they had made up their mind before the campaign. In 2010, only 49 per cent had decided before the campaign. In our polling, Labor had rebounded to a significant lead on primary votes immediately after Julia Gillard became Prime Minister. This was reversed to a six-point primary lead by the Coalition on election day. Analysis of voter groups over this period shows it was younger voters under thirty-five and those with families who were most responsible for this movement.

Shortly after becoming leader, Julia Gillard's margin over Tony Abbott as preferred prime minister was more than 25 per cent. By the last part of the campaign, however, Tony Abbott had drawn level as preferred prime minister - a remarkable achievement for an Opposition leader. Interestingly, our research showed that during the campaign Gillard's favourability fell below Rudd's and remained below it after the election.

There is no doubt that community revulsion at the way in which the faceless powerbrokers toppled an elected prime minister influenced votes, and this was also shown in our research. Economic considerations, however, were paramount: the economy, budget management, waste and taxes were all cited in our research as major spontaneous reasons for the way people decided to vote. The Coalition built and maintained a strong lead on key economic issues during the campaign. 
The Coalition's policy agenda was encapsulated in our Action Contract. Tony Abbott made a cast-iron pact with Australians to 'end the waste', 'pay back the debt', 'stop new taxes', 'help families', 'stop the boats' and 'do the right thing'.

According to our research, our positive Action Contract advertisements featuring Tony Abbott were the most effective single advertisements of the campaign. The positive nature of our campaign was particularly important in building momentum, as our research showed 69 per cent of voters chose to positively endorse a party while only 28 per cent were motivated to vote against a party.

Our success in building this positive campaign was remarkable given the strength of our opponent's negative campaign against us. It is clear the Australian Council of Trade Unions (ACTU), other unions and other left-wing groups were fully integrated into Labor's campaign, as an analysis of television advertising spending during the campaign shows. The ACTU spent $\$ 3.8$ million on antiCoalition advertising during the election campaign. GetUp! spent \$1.5 million on television advertising, assisted by union donations worth $\$ 1$ million.

There was a period of 10 days - a lifetime in a political campaign - in the first half of the election in which Labor did not advertise at all except for a minor buy in one State. But during this period, the ACTU and unions were on the air nationally attacking Tony Abbott and the Coalition.

Our post-election research showed that our members and candidates added to the Liberal Party's vote across Australia while Labor's candidates were neutral or a negative influence on their vote. Considerable work and preparation went into our marginal-seat campaigning and it was important in securing 14 additional seats for the party.

Despite the massive opposition we faced, the Coalition held to its strategy and clearly won the campaign by focusing on the key voter concerns: the cost of living, debt, deficit, waste, new taxes, lax border security, lack of competence in government service delivery and integrity in government.

Labor had no positive agenda to move Australia forward, thereby undercutting their campaign theme from the beginning. They could only resort to the same tired scare campaign they have used in previous elections. Australians do not believe minority government is good for the nation.

In the period since the election, it has been apparent Labor is a mess and that Julia Gillard is struggling. As a result, Australia is drifting. At the core of Labor's problem is that it is unable to put Australia's interests first. Everything Labor does is driven by the need to survive. What do the Greens think? What do the Independents think? How will the factions react? 
We are in an unprecedented political situation. We have a weak and unstable government that is in a mess and getting worse. We have a prime minister who is not up to the job. And we have a restless Labor Party that has already removed one prime minister and will remove another when desperation sets in.

Australia cannot afford another three years of weak government with limited ambition. The Coalition will hold Labor to account and we will push them to do better because Australian families deserve nothing less.

The contrast could not be clearer between an ineffective Labor government with no policies, no direction and weak leadership, and the Coalition with clear direction, good policies and strong leadership to make Australia a better country. Australia does need strong leadership and only one leader can provide it. Tony Abbott knows what he believes, will always make the right decision for the right reason and has what it takes to get Australia moving again to make life better for ordinary Australians.

The Coalition is the only path to a strong and prosperous Australia. We therefore have a great obligation to be ready to offer a strong alternative whenever the next election is held. Tony Abbott and the Coalition are determined to provide the leadership Australia needs and which Labor cannot provide. 